\title{
Silence and the Failure of Persuasion in Tragic Discourse
}

\author{
Vanessa Zetzmann
}

\section{1 \\ Introduction}

In Greek tragedy, we often encounter characters being silent for an extended period of time and, especially in Aeschylus' works, as noted by Taplin (1972), ${ }^{1}$ these instances of silence convey a specific dramatic effect: they draw attention to the silent character. Whilst the significance of these extended stretches of silence has been duly explored, ${ }^{2}$ shorter instances also play a role in tragic discourse:

In the context of tragic persuasion and rhetoric, characters often fail to convey their intent or proposition ${ }^{3}$ — this has mostly to do with differing character opinions or dispositions. Sometimes, however, these characters are not even able to establish communicative contact and their interlocutors stay or fall silent. Frequently, then, speakers comment on this phenomenon by using

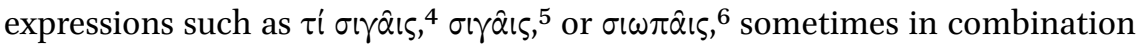

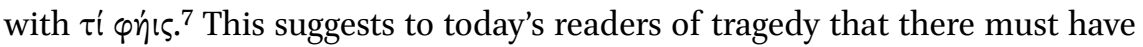

1 For Niobe und Achilles in Aesch. Myrmidones, see Taplin (1972: 58-76), also Montiglio (200o: $213^{-216)}$.

2 Cf. e.g. Chong-Gossard (2008: 113-204). For an extensive survey of silences in tragedy, see Montiglio (2000: 158-212).

3 For the case of Euripides, see Battezzato (2017).

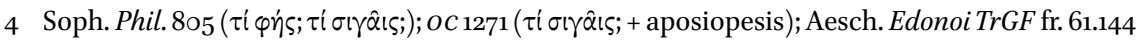

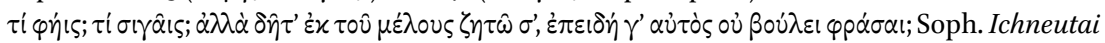

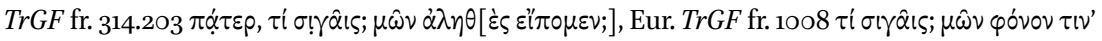

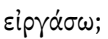

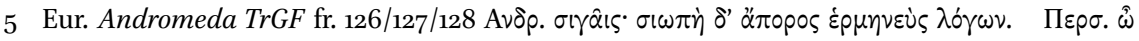

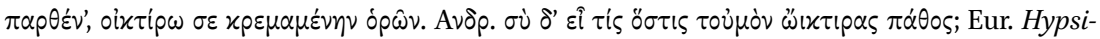

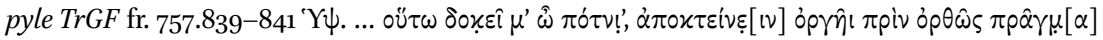

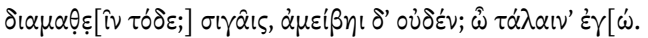

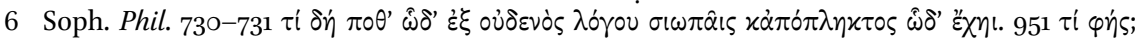

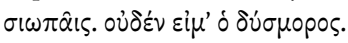

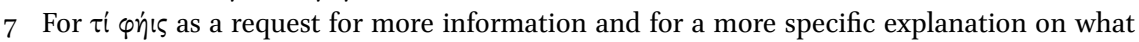
was said in conversations without silence, see e.g. Soph. El. 675, 855; ot 330, 654, 957, 1233;

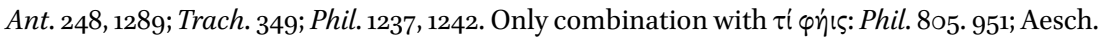
Edonoi $\operatorname{Tr} G F$ fr. 61.144 . 
been a performed and marked pause on stage: there is no communicative contact at all despite the persuasive intention of the interlocutors.

\section{Types of Silence and Their Linguistic Value}

Before asking how these breaks in contact work and what they convey in tragic discourse and on the tragic stage, an approach towards the causes ${ }^{8}$ of silence in tragedy and its possible mechanisms shall be taken by beginning with a look at Aeschylus' Agamemnon. Being probably the most famous silence scene in tragedy, ${ }^{9}$ Clytaemestra's appeal to Cassandra to enter the Argive palace offers an instructive intradramatic reflection and relevant starting-point for our survey and may even be profitably paired with modern pragmatics in order to explain other scenes: ${ }^{10}$

[1] Aeschylus Agamemnon 1035, 1039, 1050-1052, 1059-1065

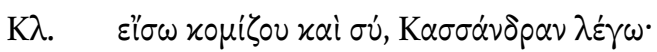

$[\ldots]$

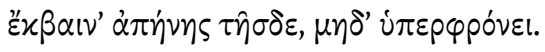

$[\ldots]$

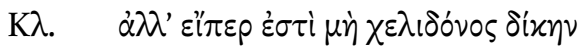

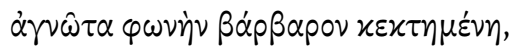

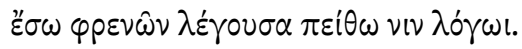

$[\ldots]$

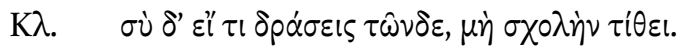

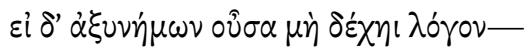

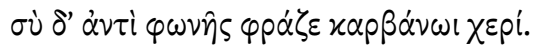

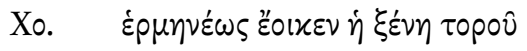

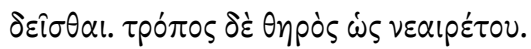

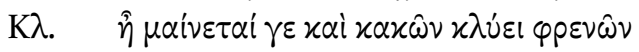

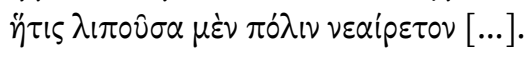

Clyt. You come along inside too-I mean you, Cassandra.

$[\ldots]$

8 Perceau (2014) offers 'réticence' and 'cri' as explanations. These binary categories, however, are, to my mind, inadequate, and I would like to search for more precise distinctions.

9 See Mastronarde (1979: 74).

10 Translations are taken from Sommerstein (2008). 
Come down from this carriage, don't be so proud.

$[\ldots]$

Clyt. Well, unless she has some unintelligible barbarian language, like the swallows do, what I say should be getting inside her mind and my words should persuade her.

$[\ldots]$

Clyt. If you want to take some part in this, don't hang around. If you don't understand my words, and they're not getting through to you, then instead of speaking, express yourself with gestures in the way foreigners do.

Cho. The foreign woman seems to be in need of a clear interpreter. She has the manner of a wild beast just trapped.

Clyt. She's mad, that's all, obeying the promptings of an unsound mind. And she doesn't yet know how to bear the bridle, not till she's foamed out her rage in blood [...].

It is striking how many unanswered imperatives ${ }^{11}$ are used by Clytaemestra and the chorus; this clearly marks Cassandra's silence as a behaviour out of the ordinary. But even more curiously, by distinguishing scenarios, ${ }^{12}$ Clytaemestra offers three possible explanations for Cassandra's unusual silence:

1) a lack of understanding of Clytaemestra's orders due to Cassandra's barbaric language (1050-1051);

2) the lack of persuasion on her own behalf (1052); and finally, as a result of her continued futile persuasive attempts,

3) Cassandra's insanity (1064). ${ }^{13}$

How can we distinguish these explanations of silence? In terms of speech act theory, the speaker's illocutionary acts are always performed in an infelicitous way when their interlocutor stays silent, meaning there is no uptake:

Unless a certain effect is achieved, the illocutionary act will not have been happily, successfully performed [...]. It cannot be said to have warned an audience unless it hears what I say and takes what I say in a certain

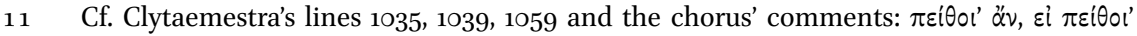
(1049) and हैं $\pi 0 v$ (1054).

12 The conditional in 1050 makes the alternative scenarios clear.

13 These interpretations given within the text are not necessarily right. Here, as the audience will have already known and as we can infer from Cassandra's very first utterance to Apollo (1073 $\hat{\omega} \pi 0 \lambda$ ov $\hat{\omega} \pi \circ \lambda$ ov), Cassandra might be insane, but in the sense of a divine madness induced by Apollo and the impact of her own prophecies. On the other hand, she might also simply be unwilling to answer.
} 
sense. An effect must be achieved on the audience if the illocutionary act is to be carried out [...]. Generally the effect amounts to bringing about the understanding of the meaning and of the force of the locution. So the performance of an illocutionary act involves the securing of uptake. $^{14}$

But we can further specify these infelicitous speech acts-none of which receives any uptake, but they are met with silence - and this is also roughly outlined in Clytaemestra's explanation:

1) locutionary ineffectiveness: the speaker's utterance achieves neither a locutionary nor an illocutionary effect. If one applies this to the example of Cassandra, one would explain her silence as a consequence of insanity or a failure to understand: Cassandra does not acoustically or mentally understand Clytaemestra's words (i.e. the locution), and therefore does not grasp their illocutionary meaning either. She indicates this by staying silent.

2) illocutionary ineffectiveness: the speaker's illocutionary speech act has been acknowledged but is wilfully ignored by the silent interlocutor, i.e. has no illocutionary effect. This would refer to Clytaemestra's plan to per-

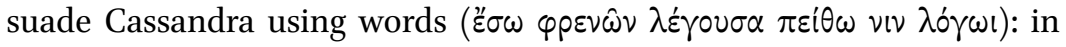
this scenario, she assumes that Cassandra has understood the meaning and the intention of her words, i.e. the illocution, perfectly, but refuses to follow. In either case, there are no perlocutionary consequences as no communicative contact is established.

But what function does silence serve in discourse? In the framework of Conversation Analysis, ${ }^{15}$ the categories of preferred and dispreferred response do not apply to an interlocutor's silence: it is neither the response usually expected ${ }^{16}$ by any speaker asking a question or making a request in their speech or turn (agreement by talking) nor a dispreferred response (rejection by talking). Since

14 Austin $\left({ }^{2} 1975: 116-117\right)$. On the correct perception of the illocutionary act as basic prerequisite for communication, see also Searle (1965: 222).

15 "'Preferred" and "dispreferred" [...] refer to sequential properties of turn and sequence construction, not participant desires or motivations.' Schegloff (1988: 445). See also Levinson (1983: 332-345). Whilst the preferred response would be agreeing by talking, rejection (i.e. not agreeing) can be classed as dispreferred responses. See Schegloff (1988: 445) and Pomerantz $(1975,1978)$.

16 Cf. the above-mentioned repeated imperatives towards Cassandra. Of course, not in every adjacency pair the preferred response is agreement by talking, e.g. self-deprecations: cf. Pomerantz (1984). 
it sometimes prefigures a dispreferred response to $\mathrm{come}^{17}$ but does not always do so (Cassandra does not answer at all to Clytaemestra), I suggest defining silence as a 'non-response.' ${ }^{18}$

Other causes of silence can also be classified by this framework, e.g. sickness or an unreceptive state of mind, as in similar scenes in Sophocles' Philoctetes and Euripides' Hippolytus. ${ }^{19}$ These examples can be termed locutionary ineffectiveness, because interlocutors were prevented from communicating by external factors and did not even grasp the implications of the request made to them.

Examples of illocutionary ineffectiveness-i.e. understanding the illocution but not being able to give a preferred response and not acting upon the recognised illocution - would be strong emotions on the interlocutor's part: in Euripides' Iphigeneia at Aulis (1238-1257), Agamemnon's grief and shame about his decision to sacrifice Iphigeneia keep him from talking, although he, of course, understands Iphigeneia's illocution. ${ }^{20}$ But there are also instances of illocutionary ineffectiveness in which the character simply refuses to answer, and their personal aversion becomes clear-they are wilfully reacting by not talking. The fathers Oedipus in Sophocles' $o c$ and Theseus in Euripides' Hippolytus when refusing to speak with their sons exemplify this use. ${ }^{21}$ Silence has therefore been shown to represent two different kinds of non-responses that are caused either by locutionary and illocutionary or merely by illocutionary ineffectiveness.

17 'Commonly, dispreferred responses are preceded by some delay component in their turn [...]' Schegloff (1988: 445).

18 See Stivers and Robinson (2006: 373); Levinson (1983: 300-301) calls this type of silence in general an 'attributable silence' as speakers have been selected to speak by their interlocutor but stay silent.

19 In Sophocles' Philoctetes (731-745), the main character falls silent and breaks contact with Neoptolemus because he is in pain and sick. In Euripides' Hippolytus (179-283), Phaedra's breaks in communication when talking to her nurse in the beginning of the play are said to be caused by sickness, which again is caused by a state of mental confusion - Phaedra herself calls this $\mu \alpha v i \alpha$, and the chorus call it vóros. Given that both her emotion and sickness are portrayed as severe, this failure to establish contact should be explained as locutionary ineffectiveness.

20 Cf. Creon's pain about the prophecy that his son Menelaus needs to be sacrificed in Euripides' Phoenissae (Eur. Phoen. 967-970).

21 Soph. OC 1271-1348: Oedipus does not want to talk to Polyneices and ignores him for a long time-there is a gap of nearly 80 lines between Polyneices' enquiring about the silence and his eliciting an indirect response by Oedipus. Likewise, in Euripides' Hippolytus (Eur. Hipp. 902-1101), Theseus does not want to acknowledge Hippolytus' arguments out of hatred. For the îंo of $o c$ 's Oedipus being represented by his silence, see Perceau (2014: $68)$. 
When considering the examples above, ${ }^{22}$ however, the paradoxical nature of silence in tragic dialogue becomes manifest: as it marks a pause in tragedy's metrical language, it must follow that silent speakers do still take up their turn despite not speaking, and, what's more, precisely by staying silent. For the types of silence discussed can also be said to have an illocutionary force and a perlocutionary effect: ${ }^{23}$ by choosing not to speak, hence by giving a non-response and still taking up a turn, interlocutors convey a deeper meaning to their reaction and a disturbing effect is achieved on the speaker. ${ }^{24}$ Silences in persuasive discourse are consequently either caused by external factors-i.e. sickness or insanity - or internal factors - such as intense emotional involvement or personal aversion. The terminology provided by speech act theory and Conversation Analysis can help classify silences and their explanations more adequately and clearly: as a result, we are able to distinguish between voluntary and involuntary silence, external or internal reasons, as well as the degree of influence of the speaker-interlocutor relationship. Observing that silent speakers take up their turn by filling it with silence points to an important dramatic meaning. ${ }^{25}$ These categories do not become eminently clear from performance or text.

\section{$3 \quad$ Strategies of Reconnecting}

We have seen what silences in persuasive discourse mean and how they are interpreted by the speakers. It will illuminate our understanding of the relev-

22 The Cassandra passage in A. Ag. offers a very clear turn-sequence, in which the chorus selects Cassandra as the next speaker, and Clytaemestra answers instead: 1049-1050 Xo.

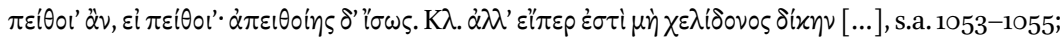
the same is true for Soph. Phil. 730-731, but Neoptolemos keeps talking after a diaeresis

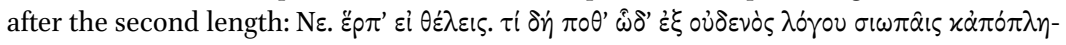

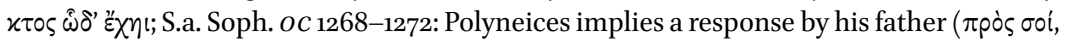

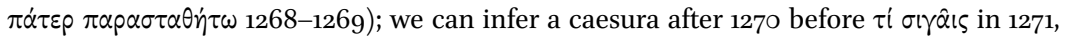
which again offers a pause as 1271 is an incomplete verse. In Eur. Hipp. 910-911, Hippolytus selects his father as the next speaker and then comments on his silence, which also sug-

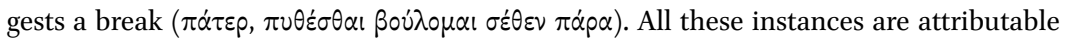
silences and effect breaks in conversational flow, which marks the absence of vocalised uptake. Therefore, attributable silences should be seen as a turn which speakers choose to or are forced (by emotional or physical impediment) to fill with a non-response.

23 I wish to thank Luis Unceta Gómez for this observation.

24 Cf. comments such as $\tau i$ $\sigma \nmid \gamma \hat{\alpha} \iota \varsigma$, which express a state of confusion and prompt the audience to wonder about the reasons.

25 Along the idea of Watzlawick et al. $(1967: 48-51)$ that one cannot not communicate, I suggest that silence is all the same a form of communication and therefore has the value of a turn. 
ant passages to examine the speakers' approach to an occurrence of silence in discourse and their attempts at reconnecting. Firstly, we should examine

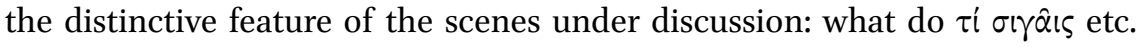
imply?26 The $\tau$ i-questions here considered seem to have a two-fold function: 1 ) they are the first verbal instance in discourse to mark this silence on stage (i.e. Wortregie) and 2) they already show some kind of reaction to the preceding silence-literally, by asking for the reason for the interlocutor's silence. ${ }^{27}$ But if

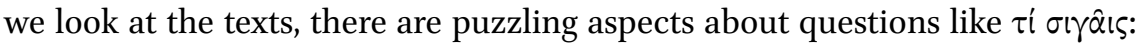
on their own, they are almost never answered in a straightforward way ${ }^{28}$ they tend not to entice a character to explain the reason for their silence, which would be the preferred response. ${ }^{29}$ Even when they are combined with

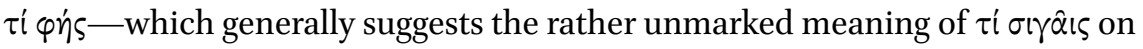
its own - they do not make the interlocutor speak instantly. ${ }^{30}$

Instances in which these questions do convince the previously silent interlocutor to reply are few and have one feature in common: they are always combined with other questions showing further personal interest for the silent interlocutor and the reason for their silence. ${ }^{31}$ So in fact, these short expressions are often only the prelude to a more engaged and interested approach by the speaker, ${ }^{32}$ and not so much a valid question of their own. Since we

26 Here, I also include the questions $(\tau i) \sigma \iota \gamma \hat{\alpha} \iota \varsigma$ and $\sigma \iota \omega \pi \hat{\alpha} \iota \varsigma$ as well as their combinations with

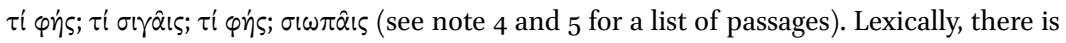
little difference between $\sigma i \gamma \hat{\alpha} \nu$ and $\sigma \omega \omega \pi \hat{\alpha} \nu$ when used intransitively: cf. Eur. IA $1245 i \delta o v$, $\sigma \omega \omega \pi \hat{\omega} \nu \lambda i \sigma \sigma \varepsilon \tau \alpha i \sigma^{\prime}$ ' $\delta \delta$ ', $\hat{\omega} \pi \alpha \dot{\alpha} \tau \varepsilon \rho$ (LSJ s.v. $\sigma \omega \omega \pi \dot{\alpha} \omega$ I. 'keep silence') and Telephus TrGF fr. 706.3-

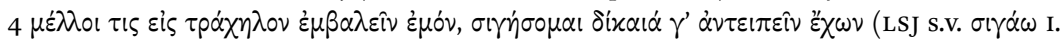
'keep silence'). For transitive use, cf. Eur. TrGF fr. $1037 \dot{\alpha} \tau \dot{\alpha} \rho \sigma \omega \pi \hat{\alpha} \nu \tau \dot{\alpha} \gamma \varepsilon \delta^{\prime}\left(x \alpha l^{\prime}\right.$ o $\chi \chi^{\prime} \chi \eta^{\prime} \pi 0 \tau \varepsilon$;

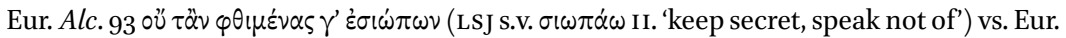

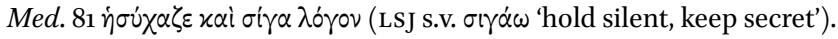

27 Montiglio (2000: 192) hints at this function when she observes: 'This phrase, by putting forward speech, betrays the agitation aroused by silence in those who try to understand this behavior and to bring it to an end.'

28 Exceptions are Soph. Phil. 806 und Eur. Andromeda TrGF fr. 126/127/128.

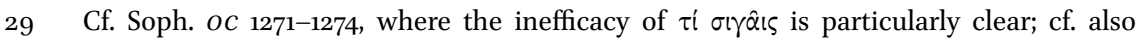
Soph. Phil. 730-735; Soph. Ichneutai, fr. 314.203-205; Eur. fr. 1008; Eur. Andromeda TrGF fr. 126/127/128; Eur. Hypsipyle TrGF fr. 757.839 .

$30 \quad$ Aesch. Edonoi $\operatorname{TrGF}$ fr. 61 (context uncertain, but at least ten more lines of rhesis); Soph. Phil. 951-952 (longer rhesis and choral song before interlocutor replies).

31 Such a case is e.g. Soph. Phil. 804-805, where we find the additional question $\pi \circ \hat{v} \pi \circ \tau^{\prime}$

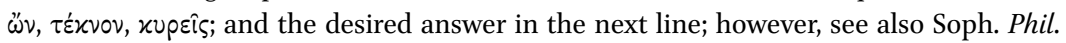
$730-73^{1}$ with the further question $\tau i$ है $\tilde{\sigma} \sigma \tau \nu$ after $\sigma \omega \omega \pi \hat{\alpha} \iota \varsigma$; cf. finally Eur. Andromeda $\operatorname{Tr} G F$

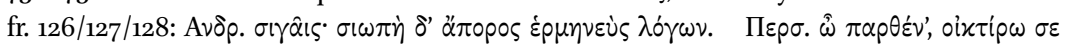

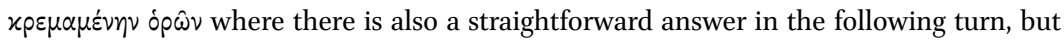
only after an additional comment on silence being hard to understand. 
have to assume a short pause after each of these questions, the interlocutor's silence is obviously marked by several missed turns. These missed turns make

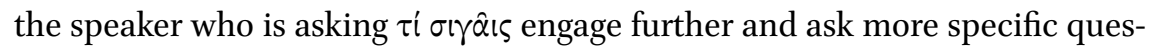
tions.

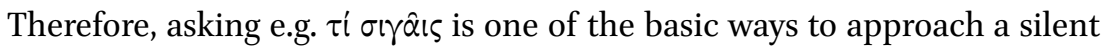

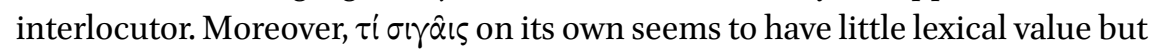
rather to be a formulaic or conventionalised expression, in the sense of a preferred response to a non-response turn within an established pattern ${ }^{33}$ - this might also be a marker for the audience, underlining the interlocutor's non-

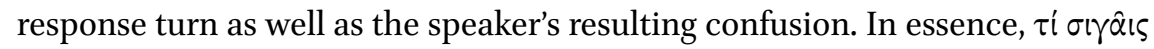
functions as a metadirective. ${ }^{34}$

Furthermore, we should examine cases in which several non-response turns are taken up by the silent interlocutor. Can we observe more involvement and interest in an interlocutor's silence than speakers using merely formulaic

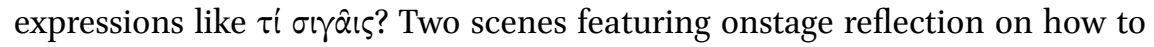
deal with someone's silence may help, as both of them refer to wilful silence due to illocutionary ineffectiveness:

Revisiting the scene in Aeschylus' Agamemnon, we find a situation without

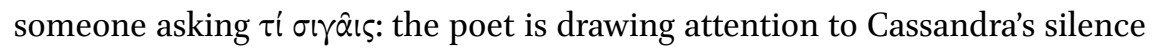
by making both Clytaemestra and the chorus each ask her three questions that do not receive an answer. As we have already seen, when pointing out a new welcoming home to Cassandra and a sacrifice within, Clytaemestra fails to make her move or talk. She hypothesises three possible reasons for Cassandra's silence: her barbaric language, her lack of understanding, or, if Cassandra does indeed rationally understand Clytaemestra, a lack of persuasive strategy on

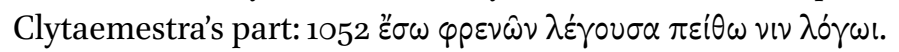

Scholars' explanations of the difficult expression है $\sigma \omega \varphi \rho \varepsilon v \hat{\omega} \nu$ differ: ${ }^{35}$ Whilst Fraenkel doubts the authenticity of हैं $\sigma \omega \varphi p \varepsilon v \omega \nu \lambda \varepsilon^{\prime} \gamma \sigma v \sigma \alpha,{ }^{36}$ Denniston and Page accept it hesitantly ('I persuade her within her mind.') on account of a paral-

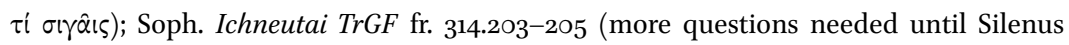
answers); Eur. $\operatorname{Tr} G F$ fr. 1008 (context unclear but combined with another question); Eur. Hypsipyle TrGF fr. 757.839 (no response for 30 lines).

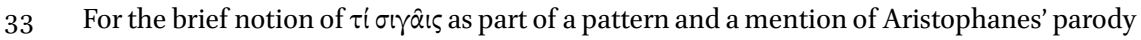
of it in Ar. Ran. 832, see Montiglio (2000: 192, 217). The need for more questions can also be explained by metrical reasons: asking only $\tau i$ $\sigma \gamma \hat{\text { â } \iota ~ m e a n s ~ t h a t ~ a n ~ e n t i r e ~ l i n e ~ w o u l d ~ b e ~}$ lost and therefore, another marked silence would occur.

34 On metadirectives in Latin persuasive contexts and other contexts, see e.g. Risselada (1993: 44-45).

35 In Eur. Med. 316 it means 'in someone's mind'.

36 Fraenkel (1950: 477-478). 
lel from the Iliad ${ }^{37}$ However, much earlier than Fraenkel as well as Denniston and Page, namely in Scholefield's 1828 edition, ${ }^{38}$ and conversely, also in more recent works, ${ }^{39}$ है $\sigma \omega \varphi \rho \varepsilon v \omega \hat{\omega} \nu \lambda \varepsilon$ ' $\gamma 0 v \sigma \alpha$ is seen as Clytaemestra's adjustment to Cassandra's $\varphi \rho \varepsilon$ v́vऽ in a persuasive context. This reflection shows that here, as Budelmann and Easterling ${ }^{40}$ have pointed out for the following scene, we can see an example of Theory of Mind in action: Clytaemestra thinks about how to adjust to Cassandra's $\varphi p \varepsilon ́ v \varepsilon \varsigma$ and therefore has a concept of Cassandra's mind as differing from her own. ${ }^{41}$ Hence, without having commented on Cassandra's silence explicitly, there is an idea that an adjustment to someone's $\varphi$ pÉveৎ is required to make them talk_ ${ }^{42}$ it is an acknowledgement of one's own failure to persuade.

Furthermore, there is another striking scene in which a break in contact marked by silence is reflected upon: when Polyneices tries to convince his father to support his cause in Sophocles' Oedipus at Colonus (Soph. oc 1271${ }^{1348)},{ }^{43}$ he begins his speech with a very negative description of Oedipus, selfdeprecation, and an appeal for pity. Then, Polyneices comments on his father's silence with $\tau i$ $\sigma \gamma \hat{\alpha} \iota \varsigma^{44}$ but in the end resorts to appealing to his sister for help in order to establish contact again. ${ }^{45}$ Antigone however refuses to do so and says the following lines-crucially, this is after Polyneices has asked $\tau i$ $\sigma \mid \gamma \hat{\alpha} \iota \varsigma^{46}$

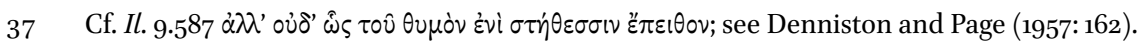
The same passage is already cited, but rejected as an insignificant parallel, by Fraenkel (1950: 477).

38 'ita loquens ut intellegat Cassandra.' Scholefield (1828: 246).

39 Raeburn and Thomas (2011: 183): 'transmitting words which Cassandra at least understands.'

40 Budelmann and Easterling (2010).

41 For a general approach to Theory of Mind in tragedy, but only with a short comment on line 1052, see Budelmann and Easterling (2010); see also Battezzato in this volume.

42 However, that adjustment of her argumentation does not, in fact, take place: she once again emphasises the upcoming sacrifice in the Argive palace and therefore implies ambiguity and imminent death for the prophetess, which the audience will have noticed as

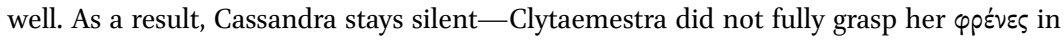

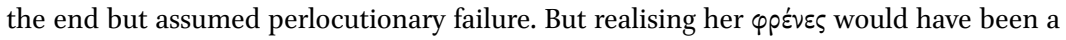
prerequisite for 1) establishing contact and 2) succeeding in her persuasion.

43 On the entire scene with an emphasis on Oedipus' response, see Saravia de Grossi (2002).

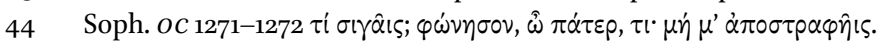

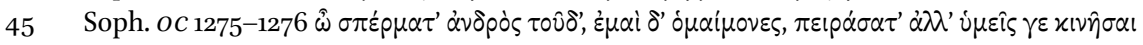
$\pi \alpha \tau$ pò...

46 My translation is based on Lloyd-Jones (1994) and has been adjusted in doubtful cases such as l. 1282. 
[2] Sophocles Oedipus at Colonus 1280-1283

$\lambda \varepsilon^{\prime} \gamma^{\prime}, \hat{\omega} \tau \alpha \lambda \alpha i \pi \omega \rho^{\prime}, \alpha \dot{\tau} \tau \dot{\jmath} \varsigma \hat{\omega} \nu \chi \rho \varepsilon^{\prime} \alpha l \pi \dot{\alpha} \rho \varepsilon l^{\circ}$

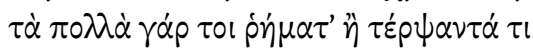

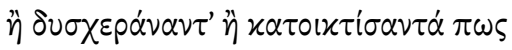

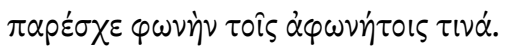

Tell him yourself, poor brother, what it is you need! For abundance of words, bringing delight or being full of annoyance or pity, can sometimes lend a voice to those who are speechless.

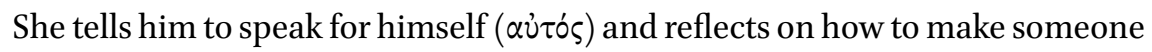

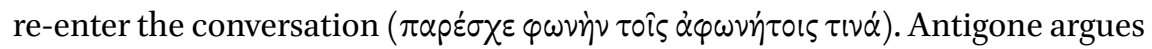
that words ( $\dot{p} \eta \dot{\mu} \alpha \tau)$ may help and specifies these as pleasing ( $\tau \dot{\varepsilon} p \psi \alpha \nu \tau \alpha)$, angry

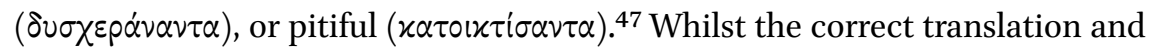
meaning of this advice has been correctly explained by Jebb, ${ }^{48}$ scholars have so far - to my knowledge - failed to see these words as a reflection on rhetorical strategy: pleasing, rebuking, or pitying someone using words in order to make them speak involves awareness of who they are and what arguments they might want to hear; and we are more likely to make them re-enter discourse if we adjust to them. In short, Antigone also implies a Theory of Mind.

By taking Clytaemestra's expression of persuading someone with regard to their $\varphi p \varepsilon ́ v \varepsilon \varsigma$ into account, we might be able to explain Antigone's advice more precisely: communicative contact, which is in the end a prerequisite for Polyneices' overall aim in this speech, i.e. persuasion, can, according to Antigone, be re-established by reacting to someone's mindset in one's speech. And as Antigone gives this advice after Polyneices has uttered $\tau i \sigma \gamma \gamma \hat{\alpha} \iota \varsigma$-in this instance probably functioning as a cue-she seems to demand that he do more than simply ask for reasons. Since this is an example of illocutionary ineffectiveness because of personal aversion, Antigone's advice makes perfect sense: interest in and engagement with the interlocutor's state of mind is crucial. Whilst at this specific point Polyneices and Antigone seem only concerned with Oedipus entering discourse again, ${ }^{49}$ Antigone's remark refers to Polyneices' general speech: it is clear that Polyneices means to achieve not just any reply from

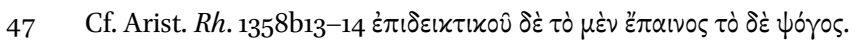

48 '[...] by giving some pleasure, —or by some utterance of indignation, or of pity' (Jebb 31900: ad 1281-1282); similarly, Saravia de Grossi (2002: 58).

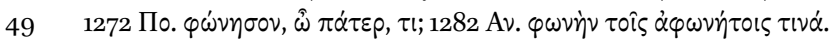


Oedipus; of course, he prefers a compassionate response from him, and so a persuasive strategy is required.

Polyneices does not entirely follow Antigone's advice: he may be using a proper captatio beneuolentiae by portraying Oedipus as the sole saviour of his Argive operation as well as arguing with his own unfortunate position as a refugee and suppliant, but then he begins his speech by addressing not Oed-

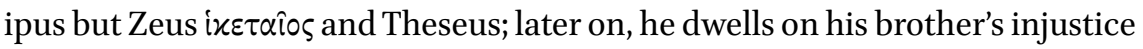
and the strength of his own army. ${ }^{50}$ Polyneices therefore does not adjust to the mind of his addressee, but focuses on himself and his own situation in order to portray himself as pitiful.

The effect this must have had on the audience is mirrored by the chorus who positively refuse Polyneices' proposition (Soph. oc 1346-1347), and later on by Oedipus, who, as we have already seen (cf. Soph. oc 1348-1396), ignores his son in his address and then rejects him. He only takes one step in a two-step process: he does, dutifully, at times, follow Antigone's advice of $\tau \dot{\varepsilon} p \psi \alpha \nu \tau \alpha$ pं $\eta^{\prime} \alpha \tau \alpha$ by stressing Oedipus' vital role in saving Thebes; but overall, he fails to do all the things necessary for effective and persuasive communication, such as addressing one's interlocutor or arguing from their point of view instead of one's own. So, it almost seems as if Polyneices makes Oedipus establish contact again by not doing what would be persuasive; instead he offers a speech that is outraged

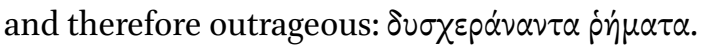

It has become clear that one needs more involvement than simply asking $\tau i$

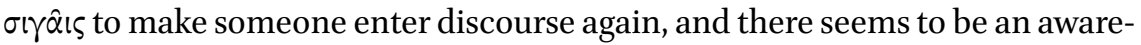
ness for the need of Theory of Mind, to speak in modern terms, within the characters' minds in order to establish contact and persuade their interlocutor. Showing interest in the interlocutor's mind was a feature in cases of both voluntary and involuntary silence (i.e. personal aversion vs. intense emotions) and underlined the speaker's confusion over this break in contact as well. $\tau i$ $\sigma \gamma \hat{\alpha} \iota \varsigma$ therefore acts as merely a marker of silence within a pattern of non-response turns, i.e. as an embedded stage direction.

50 For the clash of narratives between Oedipus and Polyneices in this passage, see Markantonatos (2007: 104-105). For a more detailed narratological interpretation, see Markantonatos (2002: 69-75). 


\section{Breaks in Contact as a Marker for Failure of Persuasion?}

By acknowledging that silence in tragedy usually represents breaks in contact due to a specific disposition of the interlocutor, questions inevitably arise about its relation to persuasion, i.e. perlocutionary force, within the dialogue in which it is embedded: does silence after one single persuasive utterance within a larger persuasive framework ${ }^{51}$ always signal the failure of all persuasive speech acts employed by the speaker? How likely is a character to give a preferred response after having already reacted with the most unwelcome non-response of all, namely silence?

Apart from Clytaemestra's failure to establish contact, it is more common for characters, such as Polyneices, to re-establish contact, but then fail in their persuasion. Two additional scenes feature a failure of persuasion prefigured by the interlocutor's silence:

In Euripides' Hippolytus (90o-945), Theseus refuses to establish communicative contact with his son after having read Phaedra's compromising letter. Hippolytus first has to establish contact but then fails to persuade him of his innocence because Theseus disrespects him. Despite Hippolytus' serious concern about his father's feelings (909-912), there is barely any straightforward communication between the interlocutors, and when Theseus finally addresses him he does so hatefully (948).

Similarly, in Euripides' Iphigeneia at Aulis (1238-1257), Agamemnon, told by the prophecy that sacrificing Iphigeneia is demanded by the gods, falls silent when his wife and daughter urge him to save Iphigeneia's life; ${ }^{52}$ Iphigeneia herself plays with her own rhetorical deficits and uses her silent young brother as a persuasive device. Although contact can be re-established, his emotional silence prefigures his emotional refusal, denying Iphigeneia her escape from the sacrifice because of his religious and moral convictions.

$5^{1}$ In this section, I exclude stichomythic passages in which contact is re-established within the next turn. See n. 27-29.

52 Agamemnon's reluctance to give a preferred response is already marked by the comments on his silence in 1141-1142, and in 1209 the chorus selects Agamemnon as the next speaker

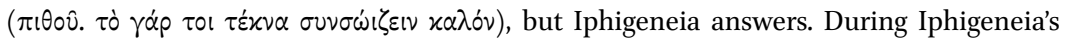
speech, this silent reluctance is made more obvious by his gestures: he looks away and refuses the physical contact with the suppliant (1239-1240). What is more, the obvious response expected by all three characters approaching Agamemnon (Clytaemestra, chorus, Iphigeneia) is a preferred response to their speech acts: Agamemnon should pledge not to kill Iphigeneia. Instead, Agamemnon wilfully refuses any contact, he gives a non-response by staying silent. 
In all these scenes (including Soph. $O c$ ), characters-after having experienced a break in contact due to illocutionary ineffectiveness-successfully re-establish contact by partially adjusting to their interlocutor, doing more than

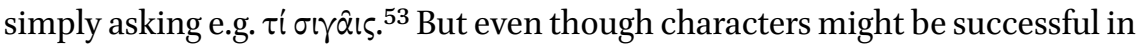
re-establishing contact, they then fail to persuade their counterparts anyway. $\tau i$

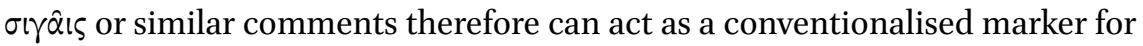
breaks in contact that typically lead to failure of persuasion, as simply uttering

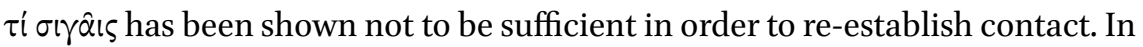
the scenes discussed in this section, silences due to illocutionary ineffectiveness and failure of persuasion are closely linked.

Successful Persuasion Despite Previous Loss of Contact: Sophocles' Philoctetes $^{54}$

Whilst the appalling aesthetic effect of Philoctetes' pain and his screaming has been noted since antiquity, ${ }^{55}$ the silences used in the very same scene also deserve attention. Earlier, we saw Neoptolemus struggling to have a proper conversation with Philoctetes (cf. Soph. Phil. 731-745 in Section 2). Philoctetes' silence due to locutionary ineffectiveness is only momentary as his pain flares up in waves. At this point, the intrigue is still in full effect with Neoptolemus pretending to save Philoctetes from the Atreidai, both have entered and exited Philoctetes' cave in order to pack up his things. But even though contact is reestablished instantly after Philoctetes' cry of pain, Neoptolemus goes on:

\section{[3] Sophocles Philoctetes $755^{-761^{56}}$}

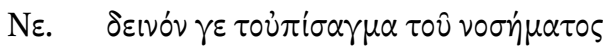

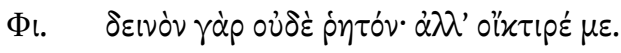

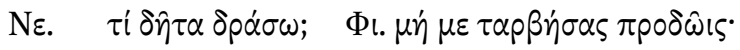

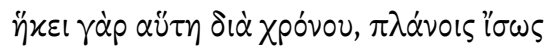

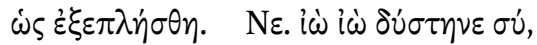

53 In Sophocles' oc, Polyneices uses a captatio; in Euripides' Hippolytus, Hippolytus asks his father questions about his pain and shows his general concern; in Euripides' $I A$, Iphigeneia asks her father to face her again and uses Orestes' presence as an emotional leverage on her father.

54 For this scene in general, see Perceau (2014).

55 See Männlein-Robert (2014).

$5^{6}$ My translation is based on Lloyd-Jones (1994) and has been adjusted in doubtful cases. 


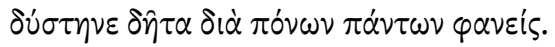

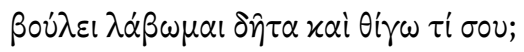

Ne. The burden of the sickness is grievous.

Phil. Grievous indeed, and indescribable!

Ne. What shall I do?

Phil. Do not take fright and betray me! It has come in person after a time, perhaps because it is weary of wandering, the sickness.

Ne. Ah, unlucky one! Unlucky you are found to be in every kind of trouble!

Do you wish me to take hold of you and hold you?

Neoptolemus acknowledges Philoctetes' wound as the source of his pain and asks what he may do about it - not only does this mean an adjustment to the interlocutor, but openly shows his intent to know the reason for his pain. Philoctetes, as a result, complies by repeating $\delta \varepsilon v v^{\prime} v$ in the same position, asks Neoptolemus to pity him, and even hands him his bow (762-773). This meaningful moment in the play when Philoctetes and Neoptolemus are portrayed as slowly developing a real emotional bond is visibly marked by contact that is lost and re-established.

Then, another bout of pain seizes Philoctetes and he cannot communicate coherently anymore. He once again screams and wishes for his death:

[4] Sophocles Philoctetes 799-806

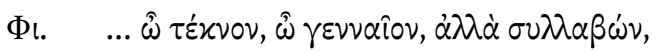

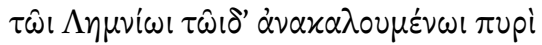

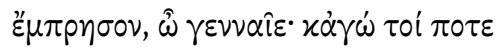

$\tau \dot{0} v \tau 0 \hat{v} \Delta$ iòs $\pi \alpha \hat{i} \delta^{\prime} \alpha \dot{\alpha} \tau i \tau \hat{\omega} \nu \delta \varepsilon \varepsilon \tau \hat{\omega} \nu$ ö $\pi \lambda \omega \nu$,

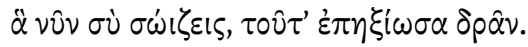

$\tau i \varphi \eta^{\prime} \iota \varsigma, \pi \alpha i$;

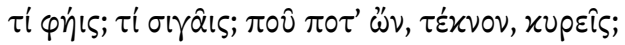

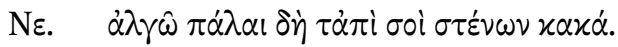

Phil. ... O my son, $\mathrm{O}$ my noble son, take me, and burn me with this fire that is invoked as Lemnian, noble one. I also once consented to do this to the son of Zeus in return for those weapons which you now are guarding! What do you say, boy? what do you say? Why are you silent? Where are you, my son?

Ne. I have been in pain long since, lamenting for your woes. 
Remarkably, Neoptolemus has now fallen silent. Philoctetes, in turn, has to

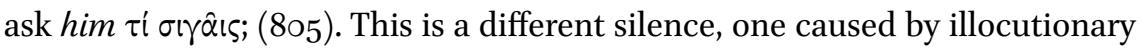
ineffectiveness, as Neoptolemus has understood Philoctetes' speech acts perfectly, but is prevented from speaking for different reasons. How does Philoctetes now, in return, re-establish contact?

He asks Neoptolemus about his current thoughts and mental state:57 805

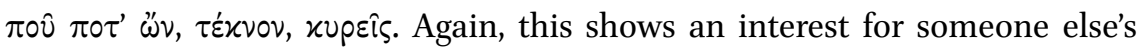
mind, which is slightly more involved than commenting on their silence. ${ }^{58}$ Neoptolemus' answer offers the reason for his silence: $\dot{\alpha} \lambda \gamma \hat{\omega} \pi \dot{\alpha} \lambda \alpha \mathrm{l} \delta \dot{\eta} \tau \dot{\alpha} \pi i$ бoi $\sigma \tau \varepsilon \dot{v} \omega \nu$ x $\alpha x \alpha \dot{\alpha}$ (806). Admittedly, this silence is an emotional one, ${ }^{59}$ having an ambiguous effect on the audience: 1 ) Neoptolemus is obviously affected by Philoctetes' excruciating pain - this has already been observed; 2) he is still pondering whether or not to follow Odysseus' plan to take Philoctetes by force. ${ }^{60}$ Again, this is a decisive moment in the play.

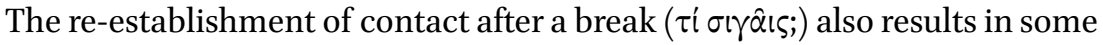
middle ground established between the interlocutors, which is unusual when comparing it to the examples we have seen: Neoptolemus even promises him to stay ${ }^{61}$ and, later on, admits that he and Odysseus had a plan (915). After hearing the revelation, Philoctetes shares his hateful monologue demanding his bow back. Neoptolemus, again, falls silent, as is marked by $\sigma \omega \tau \tilde{\alpha} \iota \varsigma$ :

[5] Sophocles Philoctetes 950-951, 961-962, 965-966

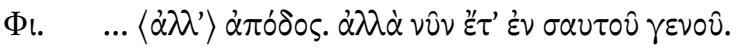

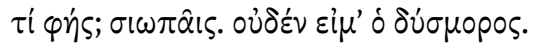

$[\ldots]$

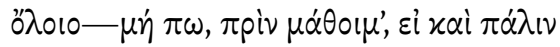

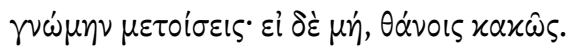

$[\ldots]$

NE.

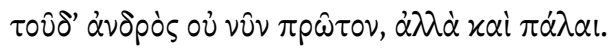

57 Schein (2013: 244).

58 Cf. Neoptolemus' engagement with the mind of his interlocutor in 729-755.

59 Cf. 'silence comme cri' Perceau (2014: 77).

6o Seth Schein rightly notices the choice of the word $\pi \dot{\alpha} \lambda \alpha \mathrm{l}$ as instructive, since it refers to the speaker's perspective and therefore implies relativity, see Schein (2013: 244).

$61 \quad 813 \dot{\varepsilon} \mu \beta \dot{\alpha} \lambda \lambda \omega \mu \dot{\varepsilon} v \varepsilon เ v$. 
Phil. ... Give it back! Even now it is not too late, come to yourself! What do you say? You are silent! I am nothing, miserable one! $[\ldots]$

May you perish — but not yet, before I learn whether you will once more change your decision. If you do not, may you die miserably! [...]

Ne. As for me, a strange pity for this man has fallen upon me, not now for the first time, but since long ago.

Again, Philoctetes makes a comment on his interlocutor's thoughts and shows awareness that is beyond simply asking why someone is silent: he debates whether he could change his mind or not. Once again, this is a sign for illocutionary ineffectiveness, as his addressee has very well understood him: $\pi$ piv

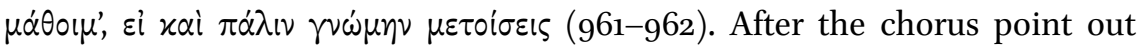
Neoptolemus' responsibility for the mission at hand, Neoptolemus finally answers with a positive response ( 965 oix $\tau$ เo $\delta \varepsilon เ v o ̀ s)$.

So why does this silence caused by illocutionary ineffectiveness-in contrast to the other scenes we have presented - raise the expectation of a positive outcome for Philoctetes? Two aspects can be employed to explain this specific outcome:

1) The interlocutor that fell silent — who was influenced by his emotionshas a reputation for his honest and friendly $\varphi v$ $\sigma \varsigma{ }^{62}$

2) Philoctetes' silence was the symptom of his severe pain; this caused Neoptolemus' silence, which was in turn a symptom of his pity and his qúrı (the two characters thus exemplify the difference between silence due to locutionary ineffectiveness and illocutionary ineffectiveness).

Characters' non-responses in the form of silence have to be interpreted by the audience and by other characters as a representation of the characters' minds: therefore, these non-responses convey the underlying dispositions of characters. Re-establishing contact that has been caused by illocutionary ineffectiveness made it possible that persuasion and synchronisation of interlocutors could be accomplished in this case. In fact, they are even furthered by silences, as Philoctetes' effectual silences only elicit the feeling of pity and concern in Neoptolemus - the embodiment of this feeling are his own silences.

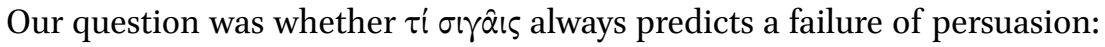
in this particular instance, we have seen that silence caused by positive emo-

$62 \quad$ Neoptolemus' distinctive character trait had already been established as early as the very first scene with Odysseus (Soph. Phil. 79-8o, 87-88). 
tions (such as pity) may predict a positive outcome. Breaks in contact therefore always ask for an engagement of Theory of Mind by the audience. To my knowledge, however, silence as a non-response seems to be more often an embodiment of negative emotions in tragedy, prefiguring a dispreferred response to the entire speech act of persuasion, and therefore predicting the failure of such.

We have considered the linguistic functions that can be attributed to silence and breaks in contact in tragedy. In the course of this study we have explored how characters tend to reconnect after a silence. Having investigated the impact of breaks in contact on the persuasive discourse they are featured in, we can draw three general conclusions:

1) Whilst silence in persuasive discourse is always a non-response, it can express either locutionary ineffectiveness, when the interlocutors did not grasp the meaning of the utterance made to them (in this case, silence in tragedy usually symbolises insanity or severe sickness); or it embodies illocutionary ineffectiveness, which mirrors positive or negative emotions on the interlocutor's part-which does not prevent them from understanding, but from answering. A special case of illocutionary ineffectiveness would be interlocutors refusing to communicate due to these emotions. Silence, marked by short pauses on stage, has also been shown to function as a turn featuring a non-response. Finally, silence can be a symptom as well as a persuasive device: it may force characters to adjust their speech, as a result of communicative contact lost. ${ }^{63}$

2) Tragic characters tend to have a concept of their interlocutor's mindwhich may be true or false-and understand that they have to use this knowledge in order to overcome silences caused by illocutionary ineffectiveness and to persuade. As we have seen, this calls for a deeper level of

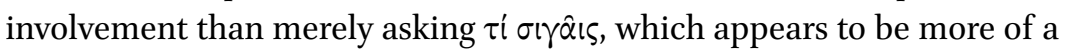
formulaic and conventionalised expression rather than conveying meaning or impact.

3) In most cases, persuasion in scenes marked by $\tau i$ $\sigma \nmid \gamma \hat{\iota} \iota \varsigma$ fails entirely because there silences express negative emotions or aversions-Philoctetes succeeds because Neoptolemus' silences are the symptom of his pity and honest $\varphi v$ vis. The notion of silence as a cue that is to be interpreted by

63 Cf. e.g. Antigone's advice and Polyneices' reaction in Soph. oc 1280-1283. 
the audience both on and off stage is therefore noteworthy, not because it draws attention to the character (as in the case of Cassandra or in Aeschylus' Myrmidones), but rather because they shift the focus towards the

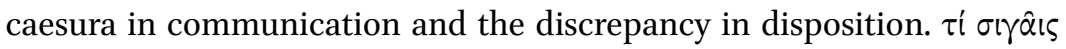
and the like therefore function as relational markers prompting the audience to pay attention to characters' $\varphi \rho \varepsilon$ ves and their ṕn $\mu \alpha \tau \alpha$ when they are trying to overcome silence in the only way in which tragic characters know how to do so: by talking.

\section{Acknowledgements}

I wish to thank the editors of this volume for their helpful remarks and thorough annotations.

\section{References}

Austin, J.L., ( ${ }^{2} 1975$ [1962]), How to Do Things with Words, Oxford.

Battezzato, L., (2017), 'Change of Mind, Persuasion, and the Emotions: Debates in Euripides from Medea to Iphigenia at Aulis', Lexis 35, 164-177.

Budelmann, F. \& Easterling, P.E., (2010), 'Reading Minds in Greek Tragedy', Greece and Rome 57, 289-303.

Chong-Gossard, J.H.K.O., (2008), Gender and Communication in Euripides' Plays: between Song and Silence, Leiden.

Denniston, J.D. \& Page, D.L., (1957), Aeschylus, Agamemnon, Oxford.

Fraenkel, E., (1950), Aeschylus, Agamemnon, vol. 2, Oxford.

Jebb, R.C., $\left({ }^{3} 1900\right.$ [1885]), Sophocles, Oedipus Coloneus, Cambridge.

Levinson, S.C., (1983), Pragmatics, Cambridge.

Lloyd-Jones, H., (1994), Sophocles, vol. 1, Cambridge, Mass./London.

Männlein-Robert, I., (2014), 'Schmerz und Schrei: Sophokles' Philoktet als Grenzfall der Ästhetik in Antike und Moderne', Antike und Abendland 6o, 90-112.

Markantonatos, A., (2002), Tragic Narrative: a Narratological Study of Sophocles' Oedipus at Colonus, Berlin/New York.

Markantonatos, A., (2007), Oedipus at Colonus: Sophocles, Athens, and the World, Berlin/New York.

Mastronarde, D.J., (1979), Contact and Discontinuity: some Conventions of Speech and Action on the Tragic Stage, Berkeley.

Montiglio, S., (200o), Silence in the Land of Logos, Princeton.

Perceau, S., (2014), 'De la réticence au cri. La gamme du silence dans la tragédie grecque', 
in L. Boulègue, P. Caye, \& C. Flament (eds.), Silence et sagesse. De la musique à la métaphysique: Les anciens Grecs et leur héritage, Paris, $65^{-89}$.

Pomerantz, A., (1975), Second Assessments: a Study of some Features of Agreements/Disagreements, Irvine.

Pomerantz, A., (1978), 'Compliment Responses: Notes on the Co-Operation of Multiple Contraints', in J. Schenkein (ed.), Studies in the Organization of Conversational Interaction, New York, 79-112.

Pomerantz, A., (1984), 'Agreeing and Disagreeing with Assessments: some Features of Preferred/Dispreferred Turn Shapes', in J.M. Atkinson \& J. Heritage (eds.), Structures of Social Action: Studies in Conversation Analysis, Cambridge, 57-101.

Raeburn, D. \& Thomas, O.R.H., (2011), The Agamemnon of Aeschylus, Oxford.

Risselada, R., (1993), Imperatives and other Directive Expressions in Latin: a Study in the Pragmatics of a Dead Language, Amsterdam.

Saravia de Grossi, M.I., (2002), 'El discurso de Polinices (vv. 1284-1345) en Edipo en Colono de Sófocles', Synthesis 9, 53-69.

Schegloff, E.A., (1988), 'On an Actual Virtual Servo-Mechanism for Guessing Bad News: a Single Case Conjecture', Social Problems 35, 442-457.

Schein, S.L., (2013), Sophocles, Philoctetes, Cambridge.

Scholefield, J., (1828), Aeschylus, Cambridge.

Searle, J., (1965), 'What is a Speech Act?', in M. Black (ed.), Philosophy in America, London, 221-239.

Sommerstein, A.H. (2008), Aeschylus, vol. 2, Cambrige, Mass./London.

Stivers, T. \& Robinson, J.D., (2006), 'A Preference for Progressivity in Interaction', Language in Society 35, 367-392.

Taplin, O., (1972), 'Aeschylean Silences and Silences in Aeschylus', Harvard Studies in Classical Philology $76,57-97$.

Watzlawick, P., Beavin, J.H., \& Jackson, D.D., (1967), Pragmatics of Human Communication: a Study of Interactional Patterns, Pathologies, and Paradoxes, New York. 